\title{
PEMBELAJARAN UPACARA PERKAWINAN ADAT JAWA MELALUI MODEL DRAMA
}

\author{
Suyoto, Bambang Sulanjari, Nuning Zaidah \\ Universitas PGRI Semarang
}

\begin{abstract}
Abstrak
Upaya pelestarian adat-istiadat sebagai budaya daerah yang merupakan aset bangsa dalam membangun kepribadian bangsa telah dilakukan, apalagi dalam budaya daerah tersebut terkandung nilai-nilai luhur untuk mengatur tatanan kehidupan masyarakat yang disebut dengan kearifan lokal termasuk salah satunya adalah upacara perkawinan adat Jawa Tengah.

Pembelajaran Bahasa Daerah (Jawa) sebagai mata pelajaran muatan lokal di wilayah Jawa Tengah memuat materi pelajaran berkenaan dengan budaya mantu (upacara perkawinan adat Jawa Tengah). Materi Budaya mantuini sebagai wujud pelestarian kearifan lokal yang diterapkan disekolah. Dalam Budaya mantu terdapat rangkaian upacara berkaitan dengan bahasan mengenai perpaduan bahasa, sastra dan seni yang dipakai dalam upacara tersebut.

Drama sebagai salah satu wujud ekspresi sastra dan seni tidak terlepas dari kehidupan manusia sehari-hari. Mengutip pendapat Kneth Macgowan, "Seorang anak menimang boneka adalah peristiwa drama" karena sesuatu yang bukan kebiasaan dan direncanakan dalam suatu sikap untuk diperhatikan pada orang lain, adalah salah satu aspek drama. Dapat disimpulkan bahwa dalam kehidupan seharihari manusia tidak lepas dari melakoni drama. Drama sebagai suatu model pembelajaran perlu dikembangkan sehingga diperoleh model pembelajaran yang memadai.

Dalam rangkaian upacara budaya mantu terdapat struktur drama yang didalamnya tema (theme), alur (plot), tokoh (character), dan tekstur adalah unsur-unsur yang menjadikan teks itu terdengar dan terlihat. Tekstur terdiri dari dialog (dialogue), suasana (mood), dan spektakel (spectacle).

Tujuan penulisan ini untuk menemukan model pembelajaran bahasa Jawa di SMA dan sederajad se-Jawa Tengahyang di dalamnya terdapat materi pelajaranbudaya mantu.Tujuan bagi siswa, mereka dapat mempelajari peristiwa budaya yang ada di sekitar lingkungan sebagai pembelajaran muatan lokal sekaligus belajar drama karena didalam upacara perkawinan adat Jawa Tengah terdapat elemen-elemen drama yang mirip dengan pementasan.
\end{abstract}

Kata kunci: drama, upacara perkawinan

Abstract
One of traditional Javanese ceremony is mantu. Mantu ceremony blended the
complexity of the using of language, arts, and literatures. Mantu had the complete
structur of drama, beginning with theme, plot, character and its texture. Tecxture
consist of dialog, mood and spectacle.
This article will show how to find the teaching model of study in senior high
school in Central Java, so the student can find the culture in their circles. Keywords: drama, marriage 


\section{PENDAHULUAN}

Pembelajaran drama di sekolah adalah pembelajaran yang berisi kajian bahasa, sastra dan seni.Jikahanya ditafsirkan sebagai pembelajaran yang membekali siswa untuk bisa mengadakan suatu pementasan, kurang efektif.Persepsiyang demikian ini lambat laun juga akan memusnahkan keberadaan drama. Padahal diakui atau tidak, drama adalah karya yang amat fleksibel, terbuka, dan menyimpan sejumlah peluang sebagai media pendidikan karakter yang disajikan dalam bentuk pertunjukan yang menarik. Melalui pembelajaran drama di sekolah, dapat dikembangkan langkah-langkah preventif untuk mewujudkan pembelajaran yang efektif dalam mengapresiasikan bahasa, sastra dan seni, serta pengembangan karakter.

Hasil observasi menunjukan bahwa model pembelajaran drama di Jawa Tengah selama ini masih tergolong statis dan kurang berkembang. Dengan demikian banyak guru pengajar mata pelajaran drama merasa kesulitan mengimplementasikan drama sebagai pembelajaran.Kesulitan lain belum adanya model pembelajaran drama yang dapat mengakomodasi pembelajaran mata pelajaran berbasis muatan lokal.

Salah satu jalur inovatif pembelajaran drama yang menawarkan perubahan menarik yaitu pembelajaran drama dengan model upacara perkawinan adat Jawa Tengah. Penyajian model pembelajaran dala penelitian ini meliputi tahap analisis perangkat model pembelajaran, pembuatan panduan model pembelajaran yang disertai dengan teaching resources(bahan-bahan pengajarannya)sebagai bahan acuan para guru pengajar mata pelajaran Bahasa Daerah SMA dan sederajad di Jawa Tengah.

\section{Tujuan Khusus}

Pembelajaranbahasa Jawa yang didalamnya terdapat bahasan mengenai budaya mantu didalamnya terdapat elemen drama, merupakan upaya mengemas suasana pembelajaran dengan menggabungkan bahasa, sastra dan seni. Pembelajaran ini bertujuan merevitalisasi adat-istiadat yang masih diberlakukan masyarakat sebagai pemberdayaan dan penguatan eksistensi tradisi agar tetap terjaga keasriannya walaupun mengalami perubahan dengan mempertimbangkan efektifitas dan kemanfaatan dari tradisi tersebut.Dengan melihat atau menghadiri upacara perkawinan adat Jawa Tengahmaka secara tidak langsung siswa dilingkungan sekolah telah belajar drama. Penggarapan dramaakan membentuk sebuah performance art yang layak ditonton. Pembelajaran drama semacam ini akan membuka peluang guru dan subjek didik memiliki kepekaan dalam berbahasa, sastra dan seni sehingga mampu memadukannya dalam bentuk pertunjukan yang estetis. Oleh karena itu, guru dan sekolah perlu mengimplementasikan pembelajaran drama dengan model upacara perkawinan adat Jawa Tengahke dalam Kurikulum, Silabus dan Rencana Program Pembelajaran (RPP) yang sudah ada. Tulisan ini bertujuan membuat rencana pembelajaran drama melalui model upacara perkawinan adat Jawa Tengah untuk siswa Sekolah Menengah Atas dan sederajad. 


\section{Muatan Lokal}

Penelitian dilaksanakan berdasarkan mata pelajaran muatan lokal yang tertera dalam UU No. 22 tahun 1999 tentang Pemerintahan Daerah,UndangUndang Republik Indonesia Nomor 20 Tahun 2003 tentangSistem Pendidikan Nasional Pasal 37 ayat (1) dan pasal38 ayat (2) dan Peraturan Pemerintah Republik Indonesia Nomor 19 tahun 2005 tentang Standar Nasional Pendidikan. Acuan bagi satuan pendidikan SD/MI/SDLB, SMP/MTs/SMPLB, SMA/MA/SMALB, dan SMK/MAN.Muatan Lokal merupakan kegiatan kurikuler untuk mengembangkan kompetensi yang disesuaikan dengan ciri khas dan potensi daerah, termasuk keunggulan daerah, yang materinya tidak dapat dikelompokkan ke dalam mata pelajaran yang ada. Substansi mata pelajaran muatan lokal dapat ditentukan oleh satuan pendidikan, tidak terbatas pada mata pelajaran keterampilan.Bahan kajian muatan lokal yang diajarkan harus bersifat utuh dalam arti mengacu kepada suatu tujuan pengajaran yang jelas dan memberi makna kepada subyek didik.

Selain itu, penelitian ini juga berpijak pada INPRES NO. 1 TAHUN 2010 tentang Penyempurnaan kurikulum dan metode pembelajaran aktif berdasarkan nilai nilai budaya bangsa makadiadakannya mata pelajaran Bahasa Daerah dalam hal ini adalah Bahasa Jawa yang di terdapat pokok bahasan budaya mantumerupakan perpaduan bahasa, sastra dan seni. Di dalam mata pelajaran tersebut terdapat pembelajaran drama yang di yang mempelajari struktur dan tekstur. Perlunyapembelajaran ini bagi guru SMA dan sederajad adalah untuk mengembangkan teaching resources pembelajaran drama melalui model upacara perkawinan adat Jawa Tengah.

Penelitian ini sebagai persiapan bagi guru SMA dan sederajad untuk mengembangkan teaching resourcespembelajaran drama melalui model upacara perkawinan adat Jawa Tengah. Dramaturgi akan membentuk sebuah performance art yang akan membuka peluang subyek didik memiliki kepekaan dalam memadukan pembelajaran sebagai pertunjukan yang estetis memupuk jiwa kreatifitas subyek didik pembelajaran di kelas dan seni menjadi terpadu. Kepaduan pembelajaran termaksud, selain akan lebih efektif dan efisien juga akan menggembirakan.

\section{Dramaturgi}

Istilah dramaturgi tidak lepas drama dengan drama seringkali diidentikkan dengan pengaruh seni peran, teater atau pertunjukan fiksi diatas panggung dimana seorang aktor memainkan karakter manusia-manusia yang lain, sehingga penonton dapat memperoleh gambaran kehidupan dari tokoh tersebut dan mampu mengikuti alur cerita dari drama yang disajikan. Dramaturgi sebagai sebuah istilah yang berhubungan dengan teater dipopulerkan oleh Aristoteles ( dalam Nur Sahid, 2008: 10-11). Istilah tersebut muncul pada tulisannya yang berjudul Poetics sekitar tahun $350 \mathrm{SM}$, sampai sekarang masih dianggap sebagai buku acuan bagi dunia drama maupun teater.Bila Aristoteles mengungkapkan dramaturgi dalam artian seni. Goffman mendalami dramaturgi dari segi sosiologi. Dramaturgi adalah pandangan interaksi tentang kehidupan sosial sebagai serangkaian 
pertunjukan dramatis yang serupa dengan yang ditampilkan di atas panggung(George Ridzer \& Douglas J. Godman, dalam Nurhadi, 2008:399)

Seperti diketahui, Goffman memperkenalkan dramaturgi pertama kali dalam kajian sosial psikologis dan sosiologi melalui bukunya, The Presentation of Self in Everyday Life(1959). Buku tersebut menggali segala macam perilaku interaksi yang dilakukan dalam pertunjukan kehidupan sehari-hari yang menampilkan diri sendiri dalam cara yang sama dengan cara seorang aktor menampilkan karakter orang lain dalam sebuah pertunjukan drama. Cara yang sama ini mengacu kepada kesamaan yang berarti ada pertunjukan yang ditampilkan. Bila Aristoteles mengacu kepada drama maka Goffman mengacu pada pertunjukan sosiologi. Pertunjukan sebagai pembelajaran diharapkan memberi kesan baik untuk mencapai tujuan.Erving Goffman menerangkan secara sederhana tentang teori dramaturgi, dengan cara melihat kesamaan antara pertunjukan drama atau teater adalah suatu "tindakan" yang dijalankan oleh seseorang dalam kehidupanseharihari (Ridzer, 2008: 234). Sebuah pementasan teater bisa dianggap merepresentasikan peristiwa dan gambaran kehidupan (Sahid, 2008, 20-21).

\section{Upacara Perkawinan adat Jawa Tengah}

Upacara perkawinan merupakan passage rites atau ritus peralihan merupakan ritual yang dialami seseorang sekali seumur hidup.Upacara perkawinan adat Jawa Tengah merupakan tradisi yang diberlakukan oleh masyarakat penyangganya. Upacar perkawinanmerupakan akibat dari rangkaian dorongan mental manusia yang dipicu oleh akumulasi kecemasan serta berbagai pengalaman yang dirasakan ganjil. Kecemasan lahir akibat keterbatasan sedangkan ganjil dikarenakan daya pikir masih berada di luar jangkauan. Upacara perkawinan memiliki beberapa aspek, selain memiliki aspek religi, eksistensi diri, menghibur juga sebagai ruang komunal. Ritual perkawinan sebagai ruang komunal diwujudkan dengan adanya berbagai kegiatan yang melibatkan komunitas, menghadirkan beberapa tokoh berperan di dalamnya dan kehadiran para peserta yang beragam. Para peserta ritual memperlihatkan kreatifitas secara keseluruhan.

Upacara perkawinan adat Jawa Tengah merupakan upacara yang memiliki nilai religi dan eksistensi budaya yang patut dilestarikan.

\section{HASIL PENELITIAN DAN PEMBAHASAN}

\section{Pembelajaran Drama dengan Model Upacara Perkawinan adat Jawa Tengah}

Pembelajaran drama merupakan bentuk utuh dari pembelajaran yang dilakukan dengan tahapan-tahapan yang sistematik sesuai dengan karakteristik konsep yang disampaikan. pembelajaran drama melalui model upacara perkawinan adat Jawa Tengah di upayakan dapat meningkatkan motivasi dan minat belajar subyek didik. Hal ini disebabkan adanya unsur pertunjukan dan keterlibatan subyek didik dalam proses belajar mengajar. Penggunaan pembelajaran drama dengan model upacara perkawinan adat Jawa Tengah merupakan suatu alternatif untuk meningkatkan daya serap siswa. Hal ini disebabkan karena pembelanjaran drama lebih aplikatif sehingga subyek didik 
memiliki pemikiran baru bahwa perhelatan dalam suatu resepsi adalah pembelajaran drama.

Struktur atau elemen drama: 1). Naskah, dalam upacara perkawinan adat jawa Tengah naskah adalah aturan-aturan yang disepakati dalam rangkaian upacara tersebut. 2). Tema sentral pada ritual panggih "Raja sehari dalam upaya keselamatan serta kehidupan bahagia dalam berumah tangga". 3). Alur merupakan simple alur, simpel alur yaitu alur lakon yang sederhana yaitu lakon yang memiliki satu alur cerita dan satu konflik yang bergerak dari awal sampai akhir. 4). Tokoh sentral atau utama dalam upacara perkawinan adalah tokoh Raja (Mempelai Putra) dan Permaisuri (pengantin Putri). Tokoh sentral atau sering disebut juga tokoh utama adalah tokoh yang banyak mengalami peristiwa dalam cerita. 5). Properti adalah semua peralatan yang dipakai dalam upacara. 6). Panggung adalah tempat dimana perhelatan dilakukan.7). Lighting adalah semua penerangan yang dipakai dalam upacara. 8). Penonton adalah para tamu undangan yang mengadiri dalam perhelatan tersebut. 9). Busana merupakan hal yang tidak bisa dipakai dalam kegiatan sehari-hari maka busana pengantin merupakan busana yang bisa di katakana sebagai busana pentas.10). Make up dan tata rambut yang dipakai oleh pengantin adalah elemen dari sebuah pertunjukan. . Pengetahuan guru terhadap drama dengan model upacara adat pengantin Jawa perlu diajarkan sehingga bisa sebagai referensi dalam mengajar sehingga dapat memberikan contoh kongkrit penerapan teori yang diberikan dengan praktik Keinginan untuk mengetahui lebih lanjut pembelajaran drama dengan model upacara adat pengantin merupakan alternative drama dapat dilihat langsung dengan memperagakan tokoh, mensetting tempat, tata iringan, lighting, property, alur, tema dan sebagainya sekaligus pengetahuan lain seperti pengetahuan bahasa sesorah dan penerapan budaya mantu implementasi guru bahasa jawa mengenai hubungan dengan kompetensi dasar.

Model pembelajaran drama diintegrasikan dalam mata pelajaran bahasa daerahbudaya mantu pada pokok bahasan mengenai perpaduan bahasa, sastra dan seni. Nilai-nilai tersebut dicantumkan dalam silabus dan RPP. Pengembangan nilainilai itu dalam silabus ditempuh melalui cara-cara berikut ini:

a. Mengkaji Standar Kompetensi (SK) dan Kompetensi Dasar (KD) pada Standar isi (SI) untuk menentukan apakah pembelajaran bahasa, sastra dan seni sudah tercakup di dalamnya.

b. Menggunakan tabel 1 yang memperlihatkan keterkaitan antara SK dan KD dengan nilai dan indikator untuk menentukan nilai yang akan dikembangkan;

1. Mencantumkankan pokok bahasan drama ke dalamsilabus dan RPP

2. Mengembangkan proses pembelajaran subyek didik secara aktif.

Adapun langkah-langkah pembelajaran yang dapat dilakukan dirumuskan sebagai berikut ini.

\section{Pendahuluan}

a. Apersepsi mengenai pengalaman berkomunikasi lisan/guru memutarkan video tentang tentang upacara perkawinan adat di Jawa Tengah.

b. Siswa menanggapi isi komunikasi siswa lain atau video yang diputarkan guru 
c. Penegasan guru atas pengalaman melihat video yang diputarkan dengan materi pelajaran drama yang akan disampaikan

2. Inti

a. Siswa diminta mengungkapkan pendapatnya tentang upacara perkawinan adat di adat Jawa Tengah yang ada di lingkungan masing-masing.

b. Guru menerangkan unsur-unsur yang ada pada drama.

c. Siswa dibentuk kelompok untuk berdiskusi kesamaan unsur drama denga peristiwa upacara perkawinan adat Jawa Tengah.

d. Setelah berdiskusi siswa diminta presentasi secara kelompok hasil temuan yang didapat dan dapat menanggapi kelompok lain.

e. Guru menegaskan dan membahas materi diskusi drama yang berkaitan dengan upacara perkawinan adat Jawa Tengah

\section{Penutup}

a. Siswa bersama guru menyimpulkan hasil diskusi

b. Guru merefleksi hasil kegiatan hari tersebut

c. Guru memberi tugas yang dikerjakan di rumah

Berkaitan dengan efektivitas pemberian model yang memadai dalam pembelajaran ramaperlu model inovatif untuk pembelajaran drama sangat memungkinkan akan disukai oleh siswa dan meningkatkan kreatifitas siswa dalam mengapresiasikan drama, para guru perlu tahu pembelajaran drama dengan model upacara adat pengantin sehingga pandangan pembelajaran drama dengan model upacara adat pengantin Jawa bermanfaat bagi kehidupan yang sekaligus dapat menerapkan praktik dengan melihat peristiwa upacara perkawinan dilingkungan masing-masing. Perkirakan pembelajaran drama dengan model upacara adat pengantin Jawa akan lebih mudah dipahami siswakarena siswa dapat melihat langsung perhelatan dilingkungan masing-masing sehingga unsur yang terkandung dalam drama dapat langsung dipahami. Pengetahuan guru terhadap drama dengan model upacara adat pengantin Jawa perlu diajarkan sehingga bisa sebagai referensi dalam mengajar sehingga dapat memberikan contoh kongkrit penerapan teori yang diberikan dengan praktik.

\section{PENUTUP}

Dengan mengimplementasikan upacara perkawinan adat Jawa Tengah kedalam pembelajaran drama merupakan upaya pelestarian adat-istiadat sebagai budaya daerah yang merupakan asset bangsa dalam membangun kepribadian bangsa yang mengandung nilai-nilai luhur untuk mengatur tatanan kehidupan masyarakat.

\section{Daftar Pustaka}

Departemen Pendidikan Nasional, Kamus Besar Bahasa Indonesia Edisi Ketiga, Jakarta: Balai Pustaka. 2005

Harymawan, RMA. Dramaturgi, Bandung: Remaja Rosdakarya, 1993.

Kernodle, George R. Invitation to the Theatre, USA: Harcourt, Brace \& World. Inc. 1967.

Sahid, Nur. Semiotika Teater, Yogyakarta: BP ISI, 2004.

----------, Sosiologi Teater, Yogyakarta: Prasista. 2008. 
Turner, Victor.The Ritual Proscess; Structure and Anti-Structure, London: Routledge and Kegan Paul. 1969.

----------, From Ritual to Theater: The Human Seriousness of Play, New York: PAJ. 1982.

----------, The Anthropology of Performance, New York: PAJ. 1988. 